\title{
FDI and the Process of European Integration A Brief Overview
}

\author{
A. Soci \\ Dipartimento di Scienze Economiche, Università di Bologna, Italy
}

\begin{abstract}
The object of this short paper is to focus on one of the many aspects of FDI - the one related to the location of industrial activity with respect to the process of European economic integration - with the aim of reviewing the most recent theoretical contributions to this topic, and to evaluate the robustness of the main empirical results. The overall evidence suggests that a precise assessment of the effects of the process of European integration on FDI and MNEs activity is far from being available. Much work has to be done especially on the data side in order to obtain a precise diagnosis of the European "new" industrial geography following integration.
\end{abstract}

- J.E.L. Classification : F210

- Key Words: FDI, Multinationals, Location

\section{Introduction}

Foreign direct investment (FDI) is an international capital movement through which a firm in a given country starts up a productive activity in another country, either with a green-field investment (implanting a new firm), or with a brown-field investment in the form of both acquisition (buying an existing firm or a part of it) and merger, with the aim of controlling the foreign firm or at least influencing substantially its running. This is the general definition given by the IMF in its updated 1993 Balance of Payments Manual and accepted by the OECD; what "control" or "substantial influence" means is left to the country-specific

\footnotetext{
*Corresponding address: Prof. Anna Soci, Department of Economics, University of Bologna 45, Strada Maggiore 40125 Bologna Italy, Tel ++39-051-2092617 Fax ++39-051-2092664 soci@ spbo.unibo.it (C)2003-Center for International Economics, Sejong Institution, All Rights Reserved.
} 
institutional arrangements. ${ }^{1}$ The immediate consequence of an FDI is that a national firm becomes, by definition, a multinational enterprise (MNE).

FDI and MNEs are a very wide topic. The subject of this short paper is just to focus on one of the many aspects of this phenomenon: the location of industrial activity in the light of the process of European economic integration. Section 2 briefly reviews the general theoretical setting which has been evolving through the 1990s. Section 3.1 focuses more on some theoretical considerations essential to assess the effects of European economic integration on MNEs activity in the form of FDI. Section 3.2 focuses on the European specificity, and Section 3.3. reviews the (very few) empirical studies on the "new" European geography. Some concluding remarks close the paper.

\section{The theoretical setting}

The theories of international-trade and business organisation both explore FDI even though it (and MNEs' activity in general) was seldom investigated by academic economists until very recently ${ }^{2}$, when two pieces of empirical evidence revived the interest in the topic: since the 1980s FDI has been growing on average more than world trade, and this growth has had the puzzling feature of concerning particularly the industrialised countries, which have been reciprocally engaged in it. The emergence of a new body of trade and location theories more eclectic in their approach made it possible to enhance the understanding of this phenomenon, whereas traditional economic theory - impermeable to the insights of business economics - was not able to fully explain it.

With the contribution of several scholars ${ }^{3}$, an "eclectic" model ${ }^{4}$ - called

${ }^{1}$ For instance: “...the US Department of Commerce defines a foreign investment as direct when a single investor has acquired a stake of $10 \%$ or more in a US firm. That firm is then considered a domestic affiliate of the foreign investor" [Graham and Krugman (1995), p. 9]. In the European Union the legislation is not jet completely uniform. In Germany, for instance, the percentage of ownership that should be used as the threshold above which investments are treated as direct investment instead of portfolio investment is $25 \%$. In Italy, where moreover the recording is mainly made through personal declaration, an acquisition of a stake of at least $20 \%$ is automatically recorded as a direct investment [Banca d'Italia (1995), p. 49 ff.]

2“"My informal estimate is that the stock of literature....appearing since 1982 is roughly as large as that published between the birth of Christ and 1982" [Caves (1996), p. IX].

${ }^{3} \mathrm{~A}$ recent overview of the main steps through which the economic theory of FDI and MNEs evolved is in Soci (2002).

${ }^{4}$ By this expression I mean the model by Markusen et al., (1996), enlarged in Markusen (1998), where horizontal, vertical MNEs, and national firms prevail over each other, due to the interplay of transport costs, size of countries, firms (and countries) factor intensity, firm-level and plant-level economies of scale. See again Soci (2002). 
"knowledge-capital model" in the literature - has been developing which is sufficiently robust to reproduce the essential theoretical features of MNEs' activity and to capture the main aspects of the current empirical evidence. Nevertheless, substantial applied analysis is required because the existence of different types of multinationals and of a wide variety of related behaviours makes it almost impossible to have a clear picture of MNEs' reactions to changes in economic and socio-political conditions. Moreover, some theoretical outlines are ambiguous and do not provide a clear testable scenario. We will shortly return to this point.

The theoretical and empirical strand which focuses on FDI and MNEs originates from both the "new trade theory" and the "new economic geography". The former allows for (static) internal economies of scale due to increasing returns, and imperfect competition as a market structure (mainly Cournot oligopoly and monopolistic competition). ${ }^{5}$ In such a framework the endogenous creation of firms as multinationals can be investigated theoretically [Helpman and Krugman (1985), Ch. 12 and 13]]. The latter - allowing for endogenous locations, which is the topic here - deserves some further attention.

Thanks to one of the founders of the "new trade theory", another close but slightly less orthodox strand of research has evolved into what is now called the "new economic geography". ${ }^{6}$ In this broad and highly fertile approach - which goes well beyond the issue under consideration here ${ }^{7}$ - the main focus is on industry-localisation, which becomes an endogenous variable through the interplay of the so-called "second nature" forces. ${ }^{8}$ The external economies (of Marshallian tradition), the backward and forward linkages (Hirschmans idea), the cumulative causation mechanism (Myrdals and Kaldors suggestion) interact in models of monopolistic competition of the Dixit-Stiglitz type with increasing returns. ${ }^{9}$ Location choices appear to be very sensitive to some key variables, transport-costs above all, with which they have a non-monotonic relationship: "As

\footnotetext{
${ }^{5}$ See as a summa of the new trade theory Helpman and Krugman (1985), where the theoretical setting is clearly defined in Ch. 2.

${ }^{6}$ The main starting reference is Krugman (1991b).

${ }^{7}$ See for instance, the most recent outcomes in Fujita et al. (1999). For a new direction of research, see Krugman (1996).

${ }^{8}$ As opposed to "first nature", which is essentially the factor-endowment.

${ }^{9}$ See Krugman (1991c).
} 
the barriers come down, there is a tendency for production to relocate to be close to the larger market ..... However, this tendency towards concentration in the centre may be offset by the fact that peripheral regions have lower wages ..... [thus, there is] a general tendency for the process of concentration to reverse itself when barriers to trade fall sufficiently .... [but] anything that impedes the necessary changes in relative wages will reinforce the tendency to concentrate production in the centre"[Krugman and Venables (1990), p. 74]. ${ }^{10}$ Thus, the greater industrial polarisation at intermediate trade-costs, ${ }^{11}$ and the possibility that the competitiveness of the peripheral countries will either improve or worsen with the fall in trade-costs represent two fundamental ambiguities that undermine any forecast about the effects of the process of European integration on "Europe's geography". Are transport costs nowadays in Europe to be considered "intermediate"? Is labour mobility nowadays in Europe sufficient to offset the fall in real wages in the periphery?

The new economic geography approach evolved through the $1990 \mathrm{~s},{ }^{12}$ and other theoretical insights were added; still, the picture is (perhaps rightly) odd. Multiple equilibria are generally present because many outcomes are possible depending on the specific assumptions of the models and on the values of the parameters as well. Complete polarisation of industry in a world divided into (industrial) core and (agricultural) periphery, multiple clusters (i.e. agglomerations of firms in narrowly defined yet geographically scattered sectors of activity), and dispersion of firms can occur as well. Broadly speaking, intra-industry trade is expected when there is industry-dispersion (at sector-level) and inter-industry trade when there is industry-concentration. The mobility of factors of production (both labour and capital, i.e. people and firms) in response to a changing context contributes to endogenizing and shaping the pattern of location, which can mutate through time. Thus so far the main body of the literature.

Nevertheless, many important and non-trivial corollaries can be added, each of them representing a strand of fertile ongoing research. The likelihood of any change (and its pace as well) in the landscape of the industrial pattern of an area

\footnotetext{
${ }^{10}$ This is a grounded outcome of the new economic geography approach. See also Venables (1996) p. 57, and Ottaviano and Puga (1998).

${ }^{11}$ Trade-costs are transport costs plus transaction costs, such as, the cost of acquiring the pieces of
information.

${ }^{12}$ For a complete survey of the new economic geography, see Ottaviano and Puga (1998).
} 
depends inter alia on the initial conditions and on the evolution of the process up to then: the "history matters" and the path-dependence issues ${ }^{13}$ - with the possible and unpleasant consequence of lock-in-type situations start to be thought of as essential ingredients of the story. Thus, institutions can have a prominent role in framing the economic environment, and they cease to be merely in the background.

The changing trend of industrial location is in turn highly responsible for the convergent (or divergent) pattern across areas (states, regions), which is today one of the main concerns with regard to European integration, and to the world development process in general. The standard measures of convergence mostly related to the rate of growth of aggregate production (and population) ${ }^{14}$ - can no longer be a good indicator of similarity, in so far as they might be hiding high concentration of different industries in different areas, with clustering of unemployment (on the hypothesis that different industries require different types of labour and on the evidence for Europe that labour is quite immobile) following the clustering of firms. This concern leads directly to the income distribution issue facing an integration process: income disparities across the regions of the EU are wide, and there is some evidence of increasing inequalities between European regions over the past decade. ${ }^{15}$ Over the same time span there is some evidence as well of a greater polarisation of unemployment rates across the regions of the EU, with unemployment clustering appearing in both the core and the periphery of the EU, often extending across borders. ${ }^{16}$ Both observations could easily be a consequence of readjustments in industrial location in Europe, following the integration process. The relevance of a full understanding of the main impact and side effects of the process of European integration is considerable for workers and for policy makers, since none of the possible outcomes is desirable in itself from the social welfare point of view. ${ }^{17}$ The market alone cannot manage agglomeration processes, since regional distribution effects will come along with the

\footnotetext{
${ }^{13}$ The usual basic references are Arthur (1988), (1989), and David (1985). See also Krugman (1991a)

${ }^{14}$ Both $\sigma$ and $\beta$ convergence - the most widely used ones - are based on per capita-income.

${ }^{15}$ See, for instance, Puga (1999), and Magrini (1999).

${ }^{16}$ The "neighbouring effect" in Overman and Puga (1999).

${ }^{17}$ For a concise but clearcut exposition of these issues, see Venables (1996), p. $58 \mathrm{ff}$
} 
consequence of exacerbating differences, rather than smoothing them. Thus, corrective measures to absorb shocks have to be implemented, and co-ordinated actions will be necessary mainly in the industrial, labour and transportation policies.

\section{The assessment of the effects of the European economic integration process on MNEs' activity in the form of FDI}

\section{A. Theoretical considerations}

Coming back to MNEs, the reasoning about where FDI go and about what is the theoretical key to interpret their geographical destination is indeed complex. In fact, one part of the international trade theory literature has been suggesting that the spread of industries (towards foreign countries) is a reaction to trade and export barriers. Thus, the obvious prediction is an investment diversion effect following a process of economic integration: a reduction of intra-regional (i.e., intra-EU) FDI, and MNEs' activities in general, is expected when trade costs and other impediments to free trade between the components of the region become less and less relevant.

Another large, and more recent, body of literature ${ }^{18}$ sees FDI as the result of the exploitation by MNEs of their intangible assets rather than a pure substitute for trade: efficiency considerations induce MNEs to spread their human capital over more than one plant, and - what matters here - more than one country. If this line of argument is accepted, the above prediction is reversed: the more substantial the economic integration, the easier to exploit this advantage and the wider the spread of MNEs' activities, specifically of those that are vertically organised and whose subsidiaries have a country-location specificity. Nevertheless, a proximityconcentration trade-off is at work: ${ }^{19}$ firm-economies of scale interact with planteconomies of scale, and the outcome is not unique. At the same time, the newly integrated economic zone is now a larger market than before, and should attract investment from the outside..$^{20}$ Thus, the overall prediction would be an increase in

\footnotetext{
${ }^{18}$ From Dunning (1977) to Markusen (1998).

${ }^{19}$ This mechanism is now part of what we called before the "eclectic" model. However, the original insight and development is in Brainard (1993) and (1997).

${ }^{20}$ See Blomstrom and Kokko (1997) p. 11, for an interesting attempt at a taxonomy of the relationship between countries characteristics and results of the integration process.
} 
interregional flows, and either a decrease or an increase in the intra-regional ones depending on which of the two contrasting forces mentioned above is the stronger.

Moreover, these movements can bring about either a situation of convergence that is, a broad homogeneous industrial picture across the components (national countries) of the area - or a situation of divergence, where industrial sub-sectors are localised differently. In fact, manufacturing sectors are noticeably different in terms of many variables; for instance, scale economies, resource content of production, backward and forward linkages, ability to create and receive spillovers can vary sectorally, thus breaking a possible trend toward "structural" convergence and bringing about a polarisation. In addition, a certain degree of path dependence that is inherent in many technological and industrial activities can slow down if not impede the process of change. ${ }^{21}$

Things are even more complicated if we consider that a pooling of industrial activities may reflect different situations. Agglomeration, concentration, or localisation?

Agglomeration should mean the grouping of firms which are not necessarily integrated from a productive point of view: Krugman's theoretical "core". It is the final outcome of large movements in heterogeneous sectors (sometimes in manufacturing activity as a whole), where the presence of firms - somehow determined by historical accident - attracts other firms in order to exploit the "agglomeration economies": mainly, the presence of skilled labour, supporting services, wide knowledge spill-overs ${ }^{22}$ (a so-called functional agglomeration).

Does industrial concentration revealed at some digits-level mean the same thing as agglomeration? Not necessarily, since the firms can be concentrated (for instance in sectors, in the 3-digit case), these sectors can happen to be in different locations, and overall agglomeration turns out to be low: sectoral industrial concentration (few firms belonging to the sector) does not mean sectoral geographical concentration, which is in turn just one of the possible outcomes of a pattern of localisation. There can be high industrial concentration without any meaningful localisation pattern. And more significantly there can be as much concentration "as it would be expected to be, had the plants in the industry chosen

\footnotetext{
21 “..the fact that higher value activity have remained so highly embedded in the core countries, while the markets for the products has increased substantially, is testimony to the continuing drawing power of established clusters of activity." [Dunning (1997b), p. 210].
}

${ }^{22}$ See Krugman (1991b), (1995), (1998), and Venables (1995), (1996). 
locations by throwing darts at a map" [Ellison and Glaeser (1997), p. 890].

And localisation? Generally speaking, and considering that there is a "natural" tendency for manufacturing activity not to be extremely dispersed, and a "natural" tendency as well for firms to be attracted by the same (unobserved) site-specific resources, localisation should mean the agglomeration of a particular industry after "controlling" for that of general manufacturing.

The importance of these considerations goes well beyond semantics and takes us straight to the problem of what measure should be used in order to evaluate properly the industrial geography. ${ }^{23}$ Agglomeration, concentration, and localisation are different concepts, while the impression is that the attempts to capture what is going on in the industrial landscape vis-à-vis the European integration process often forget this simple point or at least maintain some ambiguity about it.

\section{B. The European context}

The prediction of Krugman's core-periphery model is a clear demarcation between an industrial and an agricultural zone, which fits nicely with the American context of industrial coastal belts and an agricultural South and Midwest. In Europe, however - a fragmented area very far from the American level of integration - borders still exist and borders matter, ${ }^{24}$ even though in an ambiguous way. In fact, on the one hand continuing institutional rigidities or cultural and linguistic barriers could contribute to keeping a country relatively "isolate" even within a process of integration, giving further substance to physical borders. On the other hand, the process of integration in itself could strengthen affinities, giving rise to a kind of neighbouring effect ${ }^{25}$ where the re-organisation of economic activity produces a localisation pattern with domestic geographic

\footnotetext{
${ }^{23}$ For an assessment of this problem and for a careful use of measurement in economic geography, see Duranton and Overman (2002).

24،.... and the sheer nuisance presented by the existence of a border....[are] often enough to block the expansion of a successful industrial district beyond its national market" [Krugmanl and Venables (1996), p. 960]

${ }^{25}$ As it appears to exist in Europe, at least as far as unemployment is concerned: "Unemployment outcomes are so much more homogeneous across neighbours, than across regions in the same member State" [Overman and Puga (1999), p. 26]. On the relevance or irrelevance of borders, the same authors suggest: “...ongoing European integration may mean that national borders are becoming less important in determining regional outcomes. Geographical location may still matter however, though perhaps at levels below the nation state" [ibidem, p. 14].
} 
units (regions, for instance) tied to nearby foreign geographic units. In fact, even though trade and non-trade barriers should disappear with the completion of the internal market program, there is some evidence that border effects extend to smaller units, thus suggesting further reasons for the predominance of local trade over "international" trade. ${ }^{26}$ Since "borders" both geographical and cultural appear to matter, greater concentration in Europe could equally mean coreperiphery-type outcomes among countries or groups of countries, within countries, and among regions formed by areas belonging to different countries as well, if affinities weigh more than boundaries. ${ }^{27}$

As a final consideration, a more spurious core-periphery landscape could come about just because the forces that trigger agglomeration are relatively powerful in some sectors and weak across sectors, thus giving rise to agglomeration of each of these sectors.

Europe differs from the US also from another and not trivial point of view: the shortage of (comparable) data. This simple fact has consequences on the choice of the level of aggregation, which in turn has consequences for the results: for instance, the measures of intra-industry trade (IIT) which is strictly related to specialisation in the new trade/new economic geography theories ${ }^{28}$ - change with the level of aggregation, and the higher the latter, the lower the revealed IIT. Another problem related to aggregation is that of the product categories in the international statistics. These categories are not strictly defined in terms of similarity of input requirements, and therefore would not properly measure, again, the IIT. ${ }^{29}$ The methodology of aggregation is responsible for some striking results common to both the USA and Europe, for instance the fact that some "new" industrial activities, often technology- and scale-intensive, are recorded within "old" statistical categories, thus producing biases in the specialisation

\footnotetext{
${ }^{26}$ See Chen (2002) for a thorough study on this subject and for the reported literature.

${ }^{27}$ Still on unemployment in Europe: "These clusters do not conform to a standard core-periphery gradient. Instead high and low unemployment clusters have appeared in both the core and the periphery of the EU, often extending across national borders" [Overman and Puga (1999), p. 24].

${ }^{28}$ More precisely, high IIT means a low level of specialisation: IIT will be at the maximum if the propensities to trade are the same across products in the same industry. In the cross-country-region context, high IIT is an indicator of industrial dispersion.

${ }^{29}$ This is what Gray calls "categorical aggregation”: “..such observed intra-industry trade derives simply from the aggregation within a single trade category of goods which are quite different in terms of either input-mix or end-use" [Gray (1979), p. 87].
} 
measurement. ${ }^{30}$

Moreover, answers about the existence and the relevance of a phenomenon (industrial concentration or dispersion, in this case) can be credible or unreliable depending on the appropriateness of the variable chosen to represent it. This is a common shortcoming, but it is a particularly delicate task for Europe, given the generally poor quality and scarcity of data that force the choice of some variables rather than others. A typical example in this area is the wide use of trade data, readily available at a high level of disaggregation and comparable, instead of production data, whilst it is obvious that the latter is the right one for the evaluation of industrial specialisation and concentration. ${ }^{31}$

Even though the European reality differs from the American one, the US represent a natural - if not the only - benchmark to assess what is going on in Europe after Union has been completed. Since there is evidence [inter alia, Kim (1995), Ellison and Glaeser (1997)] of a non-random (i.e., not determined by purely idiosyncratic factors) spatial distribution of industrial activities in the US, and since economic integration is widely reputed to be one of the protagonists of the play, ${ }^{32}$ it is generally expected that the completion of European integration would lead to a re-organisation of the productive activity (and to a change in the European economic geography) in so far as it will change the incentives for agglomeration. The single currency and the reduced transaction costs should help firms in exploiting with greater efficiency some of the more intrinsic characteristics of industrial location, such as geography strictu sensu (for instance, closeness to transportation hubs) or better availability of endowment (for instance, proximity to research-labs). At the same time, integration should accelerate the process of industrial agglomeration if some profitability accrues to the firm through being close to other firms. Since the theory suggests this outcome as a likely one after the reduction in trade $\operatorname{costs}^{33}$ following greater integration, and since there is

\footnotetext{
${ }^{30}$ The high-technology sectors, which are incidentally the most interesting under the profile of the new theories, are "buried in meaningless aggregates" [Krugman (1991b), p. 59]. On this point, see also Brülhart (2000).

${ }^{31}$ For a detailed discussion on this point, see Brülhart (1998a)

${ }^{32}$ The US itself is the outcome of a past process of integration, and the recent formation of NAFTA appears to have influenced the spatial organisation of production [see inter alia, Hanson (1998)].

${ }^{33}$ Let us quote just one of the many places that enunciate this theoretical point: “..the combination of input-output linkages and imperfect competition generates forces for agglomeration of activity [that] are relatively more powerful at low trade costs" [Venables (1995), p. 299]. This statement does not contradict the one from Krugman and Venables (1990), p. 74, quoted above at p. 3.
} 
evidence [Krugman (1991b)] that industrial concentration is greater (a less dispersed and more specialised industrial geography) in the USA than in Europe, agglomeration is expected to increase in the EU as well.

\section{The empirical evidence for the European Union}

Following the prediction of the theory, through the late seventies and early eighties many scholars turned to measuring the presence of industrial concentration and agglomeration processes in the member countries, and their change through time and across space.

Even though this is the currently most analysed facet of the story, given the relative newness and the seeming attractiveness of the "geography" approach, the simpler fact of whether foreign capital has indeed been increasingly attracted by the integration in Europe has also been investigated. In fact, it is then plausible as Yannopoulos (1990), for instance, argues - that market expansion, creation of scale-economies, production efficiency and other characteristics of a customs union will promote greater innovative activity, larger R\&D, more pervasive spillovers, thus reinforcing the ownership advantages and giving stimulus to create additional direct investment. As a matter of fact, these kinds of agglomeration advantages (dynamic agglomeration economies) are reputed to be more and more important, while the easy access to inputs and to final markets are of diminishing importance ${ }^{34}$ We will briefly review the main recent results on these two strictly correlated but logically distinct themes, starting from the second one and returning later to the first. ${ }^{35}$

Yannopoulos (1990) gives an overview of the literature about the problem of the relationship between European integration and direct investment till the 1990s. The empirical debate in the late 1960s and early 1970s showed that the locational pattern of total US investment abroad changed significantly subsequent to the formation of the EC, and that the latter definitely had a strong influence on the former. Moreover, it appeared also sufficiently convincing that the process of economic integration had a definite influence on this change. The intra-EC investment too appeared to experience a change: some empirical studies reviewed in the article - revealed that the formation of a European customs union coincided with a rise in the EC non-domestic production of European Community

\footnotetext{
${ }^{34}$ See Porter (1996), pp. 86-87 for a quick assessment of this point, and Porter's research in its entirety.

${ }^{35} \mathrm{We}$ will not mention what is going on vis-à-vis the CEECs, mainly for space reasons.
} 
firms through an increase in the number of foreign subsidiaries of EC firms established in other countries of the Community. The conclusion of this first look at the relationship between the integration process and direct investment is that the latter is very likely to occur following the former, but its intensity and timing will depend on various factors, among which it would be relevant to check which kind of removal (of tariff or non-tariff barriers, respectively) is at work.

Another more recent overview of the same issue [Dunning (1997a) and (1997b)] asserts that the studies about the effect of the Internal Market Program on FDI all agreed about the fact that it was conditional upon the type of investment being considered, since they supported the relationship but they also did not deny the effect of other determinants. Thus, it is evident that the formation of the European Economic Community has stimulated MNEs' activity [Barrell and Pain (1997a), (1997b), (1999a), (1999b), Braunerhjelm et al. (2000)], and that its enlargements appears to have attracted foreign capital either from inside or outside the EC [Yannopoulos (1992), p. 329].

As far as the first theme is concerned - location and re-location of industry - a comparison of the studies on the "new" European geography" (if any) is not easy because the empirical evidence is still spotty and the results are very dependent on the measures (indices) and on the quality of data; nor are these supported, as we have seen, by well-defined theoretical outcomes that can help in discriminating among the empirical evidence. ${ }^{36}$ It is worthwhile stressing that FDI disappear from the scene when industrial location is at issue, as if FDI would not be merely the way in which agglomeration decisions become effective at an international level. As a matter of fact, the tendency towards agglomeration in FDI has not received much attention, because the perspective has been mainly regional and national, instead of international. A notable exception is Braunerhjelm and Svensson (1996), who address specifically this problem and find a positive correlation between overseas operation of Swedish MNEs and the dimension of the industry in the host countries, where firms do not yet have any affiliate production. A subsequent contribution by the same authors [Braunerhjelm and Svensson (1998)] where they also review the very few studies which tried to fill this gap in the literature specifies that this pattern of agglomeration is limited to R\&D intensive production, in line with the results of the literature on spill-overs

\footnotetext{
${ }^{36}$ On the contrary, very often in this literature the empirical findings are taken as a tool to discriminate between theories. See for instance Kim (1995) and Davis and Weinstein (1996), (1999).
} 
In the static picture, where FDI are behind the scenes, two topics are investigated in the empirical research: whether European countries have become more specialised in their manufacturing production, and whether industries have become more geographically concentrated in Europe, following the American model. We will give general answers to these questions by extrapolating the results that enjoy the broadest consensus in the scholarly contributions, which are numerically scanty but use a variety of methods and data. None deny that perhaps it is time to pay greater attention to the details of these contributions, since many of us are convinced that a lot of more and more refined empirical work is necessary; nevertheless, here we prefer just to outline the main results in a very concise but updated review, in order to fix the key findings so far relating to the European context. ${ }^{37}$

The answers given by Amiti (1998) and (1999) to the two questions recalled above using country- and industry-Gini indices based on production data for 27 manufacturing industries are both positive even though the evidence is mixed. Specialisation in Europe increased, but only six countries out of ten became more specialised between 1968 and 1990, and one did not change its industrial profile. The level of geographical concentration increased over time for seventeen out of twenty-seven industries (thirty out of sixty-five in Amiti (1999) while six of them (twelve, respectively) experienced a fall in concentration. Without entering into the details, the geographically concentrated industries are those subject to scale economies and that use a high proportion of intermediate inputs, thus "confirming" some of the new economic geography suggestions. ${ }^{38}$ These results are consistent with the ones by Brülhart Torstensson (1996), who use employment and trade data and who add some more evidence: concentration has occurred in central regions - with good market access - rather than in peripheral ones. There are also positive results about the existence of a non-monotonic relationship between intra-EU trade costs and intra-industry trade, but they are less clear-cut. Brülhart (1998b) drawing on both trade and production data again finds that the degree of industrial specialisation among EU countries has increased in the 1980s, that industries characterised by strong internal economies of scale are localised at

\footnotetext{
${ }^{37}$ See also Brulhart (1998a) and Overman et al. (2001), for a brief account of some of the papers mentioned here.

${ }^{38}$ With the caveats recalled above about the concepts of agglomeration, concentration, and location, and the data-problem.
} 
the EU core and have low IIT; that labour-intensive industries are found to be relatively dispersed over the whole of the EU, and that they have high IIT; and that according to employment data, high-tech industries in the EU are highly localised, but not along a centre-periphery gradient. Moreover, the trend concerning these industries came to a halt, whilst there appears to be greater scope for interindustry specialisation industries which are mainly sensitive to other locational determinants, such as factor costs. The fact that there is a certain degree of localisation in high-tech sectors emerges also from GuerrieriManzocchi (1996), who find different and persistent specialisation patterns in the two science-based (bio-chemicals and computers) and the two scale-intensive sectors (motor vehicles and electric/electronic goods) across the four countries considered (France, United Kingdom, Italy and Germany), thus rejecting the hypothesis of structural convergence, i.e., a broadly similar industrial landscape all over Europe. On a careful examination, this scenario could be confirmed also by a "traditional" study of convergence where the main finding is that both $\sigma$ and $\beta$ convergence show that "the income dispersion of outer peripheral regions decrease only after 1987; central regions show just an opposite pattern, that is income dispersion decreased until 1987 and then slowly increased." [Rombaldoni (1998), p. 446]. This outcome could easily be read as the welfare counterpart of the halt in the specialisation process in high-tech industries (centrally located) and the rise of a specialisation process in labour-intensive industries (more peripherally located). However, this first wave of empirical studies does not claim to offer a consistent and comprehensive description of specialisation trends in the EU.

Subsequent studies confirm the lack of a clear scenario, and also admit that there are contrasting results when different data sets are used: for instance, Brülhart (2000) finds that trade data show rising IIT (greater locational dispersion) whilst production data suggest increasing concentration and agglomeration. Again in Brülhart (2000) it appears that there is no clear evidence of agglomeration of manufacturing activities in core EU countries (17 out of 32 industries are concentrated in peripheral rather than central countries), no evidence that market integration in the EU might stimulate a more clustered industrial geography, and no evidence as well that the size of plant-specific scale economies affect significantly the specialisation level of an industry. On scale economies, Henriksen et al. (2001) support the view that there are significant differences across industries and industrial clustering regarding the level at which economies of scale both external and internal are present. Their conclusion is that external 
economies of scale, regardless of the source, are considerably less prevalent than are internal economies arising from increasing returns at the level of the national industry or firm. Thus, positive externalities in Europe appear to be limited in a geographical as well as technological sense. This is a very interesting result that deserves a further investigation since it appears to contradict recent findings from a review aimed at seeing "whether this superficial impression is confirmed upon closer examination of the literature" [Hanson (2000), p.1]. The "superficial impression" is the existence of evidence in support of the economies of scale being an explanation for spatial agglomeration. After a careful examination of the main (non-European) literature in the light of the key estimation issues, Hansons conclusion is that "the body of empirical results suggest that location-specific externalities exist and influence the spatial distribution of economic activity" [ibidem, p. 28]. Lastly, Midelfart-Knarvik et al. (2000) - in a large report prepared for the European Commission - provide many results. The most noteworthy of these are that many European countries had a significantly similar industrial structure in the 1970s, but that this trend was reversed starting in the early 1980s (result consistent with Guerrieri and Manzocchi (1996)); that European industrial structure is diverging, showing that a concentration process is under way; that approximately one half of high-tech industries which are relatively concentrated industries are moving back towards spreading over more peripheral countries; that some unskilled labour-intensive industries experienced a relative contraction and a spatial concentration in peripheral low-wage economies (these two results are consistent with Brülhart and Torstensson (1996)); that services are still more dispersed than manufacturing.

\section{Concluding remarks}

A precise assessment of the effects of the process of European integration on FDI and MNEs activity is far from being available. The most robust findings can be summarised as follows: flows of FDI from overseas and within the EU accompanied the process of European integration; agglomeration forces are at work in Europe, and they appear to have attracted FDI, even though we do not know if MNEs are relatively more active than national firms when this ongoing process is viewed on a country basis perspective: industrial structure at country level seems divergent; concentration occurred in central regions more than in peripheral ones, high-tech industries are highly localised but not along a centre- 
periphery gradient. However, much work has to be done especially on the data side in order to obtain a precise diagnosis of the European "new" industrial geography following integration.

\section{References}

Amiti, M. (1998) New Trade Theories and Industrial Location in the EU: a Survey of the Evidence, Oxford Review of Economic Policy, 14, 45-53.

Amiti, M. (1999) Specialisation Patterns in Europe, Weltwirtschaftliches Archiv, 135, 573593 (formerly Centre for Economic Performance Discussion Paper no. 363, London School of Economics, Sept. 1997).

Arthur, B. (1988) Self-reinforcing Mechanisms in Economics, in The Economy As an Evolving Complex System: Studies in the Science of complexity (Ed.) Anderson P. W. Et al. Addison Wesley, Reading, pp. 9-27.

Arthur, B. (1989) Competing Technologies, Increasing Returns, and Lock-in by Historical Events, Economic Journal, 99, 116-131.

Banca d'Italia (1995) Manuale della Bilancia dei Pagamenti in Italia: fonti statistiche e metodi di elaborazione, Roma

Barrell, R., Pain, N. (1997a) Foreign Direct investment, Technological Change and Economic Growth within Europe, Economic Journal, 107, 1770-1786.

Barrell, R., Pain, N. (1997b) The Growth of FDI in Europe, National Institute Economic Review, 160, 63-75.

Barrell, R., Pain, N. (1999a) Domestic Institutions, Agglomerations and Foreign Direct Investment in Europe, European Economic Review, 43, 925-934.

Barrell, R., Pain, N. (1999b) The Growth of FDI in Europe, in Innovation, Investment, and the Diffusion of Technology in Europe (Ed.) Barrell R., Pain N., Cambridge University Press, Cambridge, pp. 19-44.

Blomström, M., Kokko, A. (1997) Regional Integration and FDI, NBER WP no. 6019 (and also CEPR DP no. 1659, June 1997).

Brainard, L. S. (1993) A Simple Theory of Multinational Corporations and Trade with a Trade-off between Proximity and Concentration, NBER WP no. 4269.

Brainard, L. S. (1997) An Empirical Assessment of the Proximity-Concentration Tradeoff between Multinational Sales and Trade, American Economic Review, 87, 520-544 (formerly NBER WP no. 4580, 1993).

Braunerhjelm, P. et al. (2000) Integration and the Regions of Europe: How the Right Policies Can Prevent Polarisation, CEPR, Monitoring European Integration no. 10.

Braunerhjelm, P., Svensson, R. (1996) Host Country Characteristics and Agglomeration in Foreign Direct Investment, Applied Economics, 28, 833-840.

Braunerhjelm, P., Svensson, R. (1998) Agglomeration in the Geographical Location of Swedish MNEs, in The geography of multinational firms (Ed.) Braunerhjelm, P., Ekholm, K., Kluwer, Boston, pp. 99-115. 
Brülhart, M. (1998a) Economic Geography, Industry Location and Trade: the Evidence, World Economy, 21, 775-801.

Brülhart, M. (1998b) Trading Places: Industrial Specialization in the European Union, Journal of Common Market Studies, 36, 319-346.

Brülhart, M. (2000) Evolving Geographical Specialisation of European Manufacturing Industries, mimeo.

Brülhart, M., Torstensson, J. (1996) Regional Integration, Scale Economies and Industry Location in the European Union, CEPR DP no. 1435.

Caves, R. (1996) Multinational Enterprise and Economic Analysis, $2^{\text {nd }}$ ed., Cambridge University Press, Cambridge.

Chen, N. (2002) Intra-national Versus International Trade in the European Union: Why Do National Borders Matter?, CEPR WP no. 3407.

David, P. A. (1985) Clio and the Economics of QWERTY, American Economic Review, Paper and Proceedings, 75, 332-337.

Davis, D. R. Weinstein, D. E., (1996) Does Economic Geography Matter for International Specialization?, NBER WP no. 5706.

Davis, D. R. Weinstein, D. E. (1999) Economic Geography and Regional Production Structure: an Empirical Investigation, European Economic Review, 43, 379-407.

Dunning, J. H. (1977) Trade, Location of Economic Activity and the MNE: a Search for an Eclectic Approach, in The International Allocation of Economic Activity (Ed.) Ohlin, B. et al., McMillan, London, pp. 395-418.

Dunning, J. H. (1997a) The European Internal Market Programme and Inbound Foreign Direct Investment, Part I, Journal of Common Market Studies, 35, 1-30.

Dunning, J., H. (1997b) The European Internal Market Programme and Inbound Foreign Direct Investment, Part II, Journal of Common Market Studies, 35, 189-223.

Duranton, G., Overman, H. (2002) Testing for Localisation Using Micro-Geographic Data, CEPR WP no. 3379.

Ellison, G., Glaeser, E. L. (1997) Geographic Concentration in US Manufacturing Industries: a Dartboard Approach, Journal of Political Economy, 105, 889-927.

Fujita, M., et al. (1999) The spatial economy, MIT Press, Boston.

Graham, E. M., Krugman, P. R. (1995) Foreign Direct Investment in the USA, Institute for International Economics, Washington.

Gray, P. H. (1979) Intra-Industry Trade: the Effects of Different Levels of Data Aggregation, in On the Economics of Intra-Industry Trade (Ed.) Giersch H., J.C.B.Mohr, Tubingen, pp. 87-110.

Guerrieri, P., Manzocchi, S. (1996) Patterns of Trade and Foreign Direct Investment in European Manufacturing: "Convergence" or "Polarisation", Rivista Italiana degli Economisti, I, 213-231.

Hanson, G., H. (1998) North American Economic Integration and Industry Location, Oxford Review of Economic Policy, 14, 30-44.

Hanson, G. H. (2000) Scale Economies and the Geographic Concentration of Industry, NBER WP no. 8013. 
Helpman, E., Krugman, P. R. (1985) Market Structure and Foreign Trade, MIT Press, Boston.

Henriksen, E. et al. (2001) Economies of Scale in European Manufacturing Revisited, CEPR DP no. 2896.

Kim, S. (1995) Expansion of Markets and the Geographic Distribution of Economic

Activities: the Trends in U.S. Regional Manufacturing Structure, 1860-1987,

Quarterly Journal of Economics, CX, 881-908.

Krugman, P. R. (1991a) History Versus Expectations, Quarterly Journal of Economics, 106, 651-67.

Krugman, P. R. (1991b) Geography and Trade, MIT Press, Boston.

Krugman, P. R. (1991c) Increasing Returns and Economic Geography, Journal of Political Economy, 99, 483-499.

Krugman, P. R. (1995) Development, Geography, and Economic Theory, MIT Press, Boston.

Krugman, P. R. (1996) The Self-Organizing Economy, Blackwell, Oxford.

Krugman, P. R. (1998) Whats New About the New Economic Geography?, Oxford Review of Economic Policy, 14, 7-17.

Krugman, P., Venables, A. J. (1990) Integration and the Competitiveness of Peripheral Industry, in Unity With Diversity in the European Community (Ed.) Bliss, C., Braga de Macedo, J., Cambridge University Press, Cambridge, pp. 56-75.

Krugman, P., Venables, A. J. (1996) Integration, Specialisation and Adjustment, European Economic Review, 40, 959-67.

Magrini, S. (1999) The Evolution of Income Disparities Among the Regions of the European Union, Regional Science and Urban Economics, 29, 257-281.

Markusen, J. R. (1998) Multinational Enterprises and the Theories of Trade and Location, in The Geography of Multinational Firms (Ed.) Braunerhjelm, P., Ekholm K., Kluwer, Boston, pp. 9-32.

Markusen, J. R. et al. (1996) A Unified Treatment of Horizontal Direct Investment, Vertical Direct Investment and the Pattern of Trade in Goods and Services, NBER WP no. 5696.

Midelfart-Knarvik, K. H. et al. (2000), The Location of European Industry, Report prepared for the Directorate General for Economic and Financial Affairs, European Commission.

Ottaviano, G. I. P., Puga, D. (1998) Agglomeration in the Global Economy: a Survey of the New Economic Geography, World Economy, 21, 707-731.

Overman, H. G., Puga, D. (1999) Unemployment Clusters Across European Regions and Countries, CEPR DP no. 434.

Overman, H. G. et al. (2001) The Economic Geography of Trade, Production and Income: a Survey of the Empirics, CEPR DP no. 2978.

Porter, M. E. (1996) Competitive Advantage, Agglomeration Economies and Regional Policies, International Regional Science Review, 19, 85-94.

Puga, D. (1999) The Rise and Fall of Income Inequalities, European Economic Review, 
43, 303-334.

Rombaldoni, R. (1998) Core and Periphery Patterns of Regional Convergence in Europe, Rivista Italiana degli Economisti, III, 419-457.

Soci, A. (2002) FDI: the Current State of Play, DSE Working Papers no. 454, University of Bologna.

Venables, A. J. (1995) Economic Integration and the Location of Firms, American Economic Review Papers and Proceedings, 85, 296-300.

Venables, A. J. (1996) Localization of Industry and Trade Performance, Oxford Review of Economic Policy, 12, 52-60.

Yannopoulos, G. N. (1990) Foreign Direct Investment and European Integration: the Evidence from the Formative Years of the European Community, Journal of Common Market Studies, XXVIII, 235-259.

Yannopoulos, G. N. (1992) Multinational Corporations and the Single European Market, in Multinational Investment in Modern Europe: Strategic Interaction in the Integrated Community (Ed.) Cantwell, J., Edward Elgar, Aldershot, UK, pp. 329-348. 